\title{
Analysis of the Presence, Location and Morphometry of the «Alveolar Antral Artery» by Cone-Beam Computed Tomography in Chilean Adults
}

\author{
Análisis de la Presencia, Ubicación y Morfometría de la Arteria Alvéolo-Antral \\ por Tomografía Computarizada de Haz Cónico en Adultos Chilenos
}

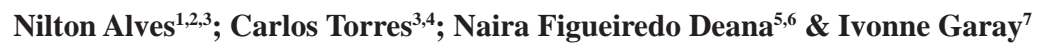

ALVES, N.; TORRES, C. ; DEANA, N. F. \& GARAY, I. Analysis of the presence, location and morphometry of the «alveolar antral artery» by cone-beam computed tomography in Chilean adults. Int. J. Morphol., 38(6):1760-1766, 2020.

SUMMARY: The posterior superior alveolar artery is responsible for the vascularisation of the mucous which covers the posterior wall of the maxillary sinus, pulp and the periodontal tissues of upper molars. The collateral rami of the infraorbital artery irrigate the mucous of the anterior and lateral walls of the maxillary sinus, as well as the pulp and periodontal tissue of the upper anterior teeth and upper premolars. Both these arteries present intraosseous and extraosseous rami which form an anastomosis in the anterior and lateral walls of the maxillary sinus, called the alveolar antral artery (AAA). The aim of this study was to analyse the presence, location and morphometry of the AAA in a Chilean population, considering sex, side and age, using Cone-Beam computed tomography (CBCT). Forty-two CBCT examinations of Chilean adults were evaluated to analyse the presence, location (extraosseous, intraosseous or subperiosteal) and diameter ( $<1 \mathrm{~mm}, 1-2 \mathrm{~mm}, 2-3 \mathrm{~mm},>3 \mathrm{~mm}$ ) of the AAA and the distance from the AAA to the amelocemental limit of the upper second premolar (2PM), permanent upper first molar (1M) and permanent upper second molar (2M) by sex and age range. Pearson's chi-squared test, Student's t-test, ANOVA and Pearson's correlation coefficient were applied, using a significance threshold of $5 \%$. AAA was found in 75 sides $(89.3 \%), 38$ on the right side $(90.5 \%)$ and 37 on the left $(88.09 \%)$; extraosseous location was most common. More than $80 \%$ of the arteries presented a diameter between 1 and $2 \mathrm{~mm}$, with no important differences between sexes or age ranges. In younger individuals, the artery was located closer to the vestibular amelocemental limit than in older individuals. Carrying out a proper treatment plan which includes imagenological analysis before surgical procedures is essential to avoid possible haemorrhagic events in the region.

KEY WORDS: Alveolar antral artery; Cone-beam computed tomography: Anastomosis; Posterior superior alveolar artery; Infraorbital artery; Anatomy.

\section{INTRODUCTION}

The posterior superior alveolar artery (PSAA) is responsible for the vascularisation of the mucous which covers the posterior wall of the maxillary sinus, pulp and periodontal tissues of upper molars. The collateral rami of the infraorbital artery (IOA) irrigate the mucous of the anterior and lateral walls of the maxillary sinus, as well as the pulp and periodontal tissue of the upper anterior teeth and upper premolars (Alves \& Cândido, 2016). Both these arteries present intraosseous and extraosseous rami which form an anastomosis in the anterior and lateral walls of the maxillary sinus, called the alveolar antral artery (AAA) (Kang et al. 2013; Alves \& Cândido). This anastomosis is at risk of lesions and can restrict

\footnotetext{
${ }^{1}$ Center of Excellence in Surgical and Morphological Research (CEMyQ), Faculty of Medicine, Universidad de La Frontera, Temuco, Chile. e-mail: nilton.alves@ufrontera.cl, ORCID ID: 0000-0001-7878-1810

2 Applied Morphology Research Center (CIMA), Faculty of Dentistry, Universidad de La Frontera, Temuco, Chile.

${ }^{3}$ Master of Science Program, Mention Morphology, Faculty of Medicine, Universidad de La Frontera, Temuco, Chile.

${ }^{4}$ Department of Morphological Sciences, Faculty of Medicine and Sciences, Universidad San Sebastián, Valdivia, Chile. E-mail: ctorresv@ docente.uss.cl

${ }^{5}$ Center for Research in Epidemiology, Economics and Oral Public Health (CIEESPO), Faculty of Dentistry, Universidad de La Frontera, Temuco, Chile. naira.figueiredo@ufrontera.cl

${ }^{6}$ Department of Paediatric Dentistry and Orthodontics, Faculty of Dentistry, Universidad de La Frontera, Temuco, Chile

${ }^{7}$ Center for Research and Innovation in Clinical Dentistry, Faculty of Dentistry, Universidad de La Frontera, Temuco, Chile. e-mail: ivonne.garay@ufrontera.cl
} 
the dimensions of the bone window during any procedure in the region, such as elevation of the maxillary sinus floor (Mardinger et al., 2007; Rysz et al., 2014). One possible intraoperative complication of elevation of the maxillary sinus floor with lateral approach is the occurrence of a haemorrhagic event due to lesion of the AAA (Stacchi et al., 2017). Lesion of the AAA can cause intense bleeding, obscuring the surgeon's view, and can lead to accidental perforation of the sinus membrane (Ella et al., 2008). Bleeding due to transection of small-diameter arteries during surgical procedures does not normally cause serious problems, and can be controlled easily with electrocauterization (Maridati et al., 2014). With largediameter arteries, however, it is more difficult to establish haemostasis, as well as increasing the risk of accidental perforation of the sinus membrane (Maridati et al.). Complications during surgery to elevate the maxillary sinus floor can cause a higher implant failure rate (Khoury, 1999), reduced bone formation (Nolan et al., 2014) and reduced stabilisation of particulate graft material due to perforation of the membrane (Wallace et al., 2012). It is essential to avoid complications during procedures in the region of the lateral wall of the maxillary sinus, to obtain a higher success rate in treatment; anatomical knowledge of the AAA and proper preoperative evaluation by X-ray are therefore essential to reduce the risk of complications during surgical procedures. The AAA is always present in the wall of the maxillary sinus, however its location, diameter and distance from the alveolar crest can vary (Maridati et al.). The aim of this study was therefore to analyse the presence, location and morphometry of the AAA in Chilean individuals, considering sex, side and age, using Cone Beam computed tomography (CBCT).

\section{MATERIAL AND METHOD}

A descriptive, retrospective, observational crosssectional study was carried out. The sample was nonprobabilistic, by convenience. We examined all the CBCT images taken between May and October 2019 as part of the diagnosis and/or treatment planning of patients who attended the Teaching Clinic of Universidad de La Frontera, Temuco, Chile. All the patients involved in this study signed an informed consent which stated their free right to participate in the study or not, with no influence on their dental treatment. The study was approved by the Scientific Ethics Committee of Universidad de La Frontera , No. 067-19.

CBCT examinations of Chilean adults of both sexes were included. Examinations were excluded in which fractures and/or surgery of the maxillary sinus were observed which might affect the interpretation of the tomographies, and images containing congenital anomalies associated with the maxillary bone.

The presence of the AAA was analysed in the anterior and lateral walls of the maxillary sinus using coronal sections. All the measurements were carried out by a previously calibrated researcher; intra-observer analysis was performed. The location of the AAA was classified as intraosseous (Fig. 1A), below the membrane (Fig. 1B) and on the outer cortex of the lateral sinus wall, following Güncü et al. (2011). The location of the AAA was analysed by sex, side and age range.

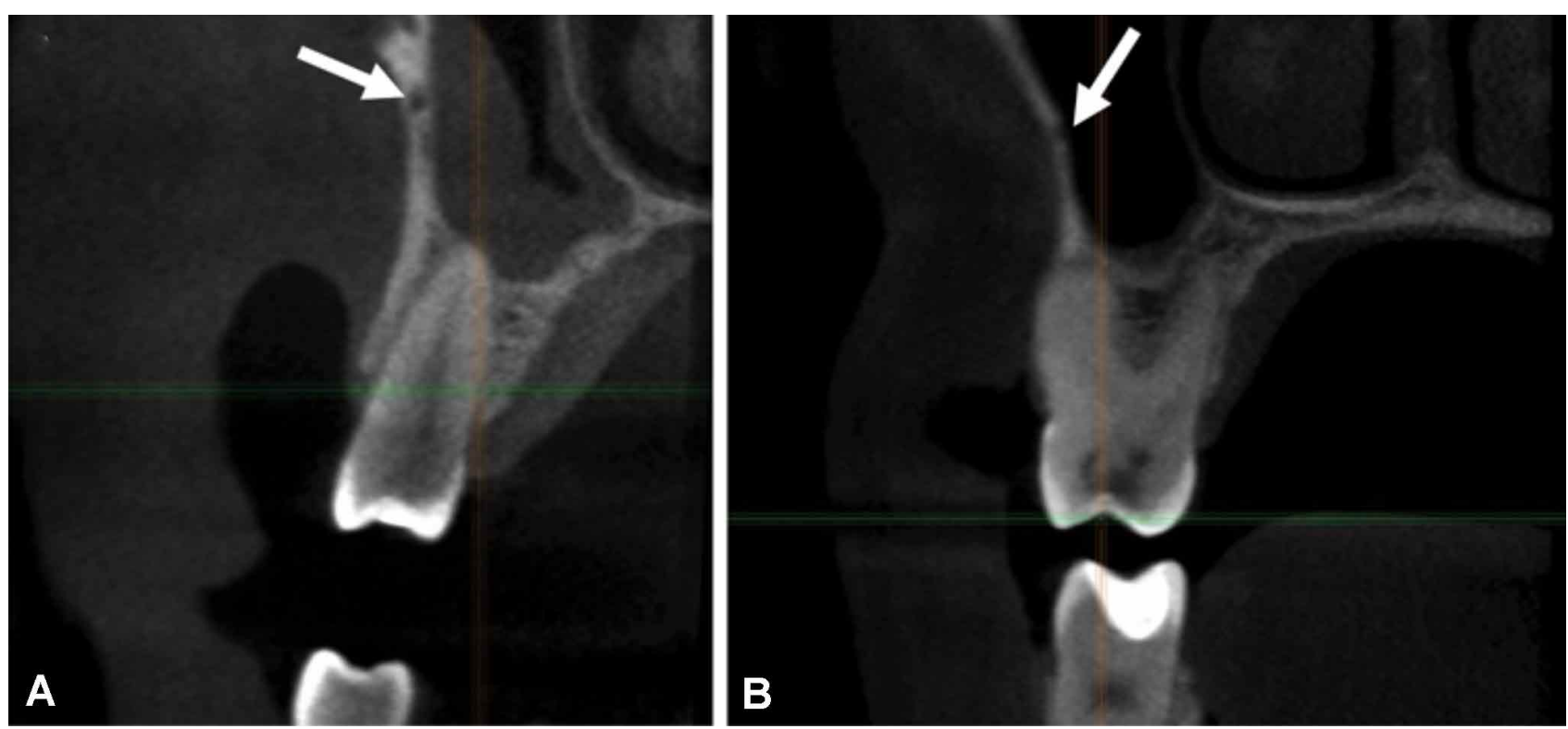

Fig. 1. Coronal section in CBCT. A. Intraosseous AAA (arrow) at the level of the right second premolar. B. Sub-periosteal AAA (arrow) at the level of the right permanent upper first molar. 
The diameter of the AAA was analysed by sex, side and age range. The diameter was classified as $<1 \mathrm{~mm}$, between 1 and $2 \mathrm{~mm}$, between 2 and $3 \mathrm{~mm}$ and $>3 \mathrm{~mm}$, as proposed by Mardinger et al. The association between the diameter and location of the AAA and the association between sides were analysed for the variables location and diameter of the AAA. For analysis by age range, the sample was divided into the following ranges: 18-28 years; 29-39 years; 40-49 years; > 50 years.

We also determined the distance from the AAA to the vestibular amelocemental limit in the following regions: upper second premolar (AAA-2PM), permanent upper first molar (AAA-1M) and permanent upper second molar (AAA2M) (Fig. 2).

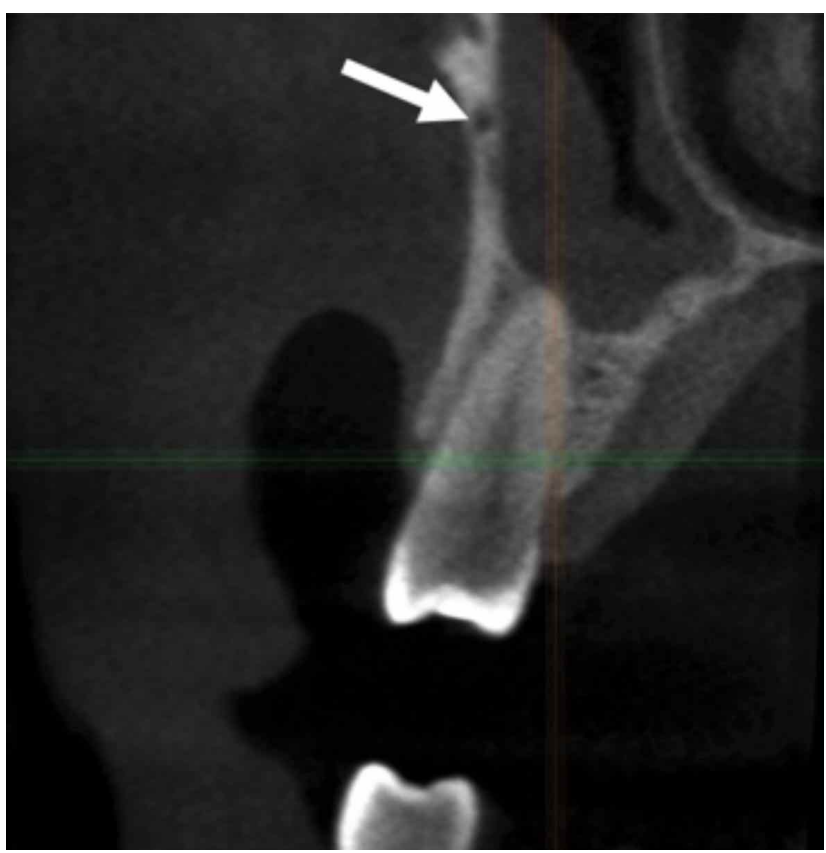

Fig. 2. Coronal section in CBCT showing the measurement from the AAA to the vestibular amelocemental limit in the right upper second premolar.

The CBCT examinations were carried out with a PAX Zenith 3D Tomograph (Vatech Co., Gyeonggi-Do, Korea), FOV $12 \times 9 \mathrm{~cm} . / 8 \times 6 \mathrm{~cm}$. The images were taken at 120 $\mathrm{kV}, 10 \mathrm{~mA}$, with exposure time of 24 seconds. The measurements of the images were calculated with the Ez3D Plus software (E-WOO Technology Co, Ltd. Korea), with voxel size $0.2 \mathrm{~mm}$. $(12 \times 9 \mathrm{~cm}) / 0.12 \mathrm{~mm}$. $(8 \times 6 \mathrm{~cm})$.

Statistical analysis. The intraclass correlation coefficient (ICC) and the kappa test were used for intra-observer analysis. The association was classified as poor (0.0), slight (0.01-0.20), regular (0.21-0.40), moderate (0.41-0.60), substantial (0.61-0.80) and almost perfect (0.81-1.00).
Levene's test was applied to test homogeneity of variances and the Kolmogorov-Smirnov test to analyse the normality of the data. Pearson's chi-squared test was used for qualitative variables: comparison of presence between sides, sexes and age ranges. The strength of association between the variables was evaluated by the Phi coefficient (f). The strength of association was interpreted as suggested by Cohen (1988), being classified as small (0.10), medium (0.30), large $(0.50)$ or very large $(\geq 0.70)$. Student's t-test for dependent samples was used for analysis between sides and Student's ttest for independent samples for analysis between sexes. Oneway ANOVA was used for analysis between age ranges. Pearson's correlation coefficient was used to analyse the relation between left and right sides for the distances (AAA2PM, AAA-1M, AAA-2M) and for the diameter of the AAA. The age-diameter ratio was also analysed. Pearson's correlation was classified as nil $(\mathrm{r}=0)$, very low $(0<\mathrm{r}<0.2)$, low $(0.2>r>0.4)$, moderate $(0.4<r<0.6)$, high $(0.6>r>0.8)$, very high $(0.8<\mathrm{r}<1)$ and perfect $(\mathrm{r}=1)$. GraphPad Prism software was used for the figures. SPSS software v. 22.0 was used for statistical analysis, with a significance threshold of $5 \%$.

\section{RESULTS}

The intra-observer analysis presented an almost perfect concordance index $(>0.8)$ in all the analyses. Forty-two CBCT examinations were used (84 maxillary sinuses) of patients aged between 18 and 61 years (mean 29.05 years, $\mathrm{SD}=13.04$ years), 15 women $(35.7 \%)$ and 27 men $(64.3 \%)$.

Presence of AAA. AAA was found in 75 sinuses $(89.3 \%)$ : 38 on the right side $(90.5 \%)$ and 37 on the left $(88.09 \%)$. No differences in the presence of AAA were found between sides $(\mathrm{p}=0.124)$. AAA was present in $90 \%$ of women and $88.9 \%$ of men, with no statistically significant difference in presence of AAA between sexes $(\mathrm{p}=0.875)$.

Location of the AAA. In the 2PM region we observed that the highest number of AAA were located on the outer cortex of the lateral sinus wall $(57.3 \%)$, followed by intraosseous $(33.3 \%)$ and below the membrane $(9.3 \%)$ (Fig. 3). In the $1 \mathrm{M}$ region we observed that the highest number of AAA were located on the outer cortex of the lateral sinus wall (49.3\%), followed by intraosseous $(27.4 \%)$ and below the membrane (23.3\%) (Fig. 3). In the $2 \mathrm{M}$ region we observed that the highest number of AAA were located on the outer cortex of the lateral sinus wall $(45.3 \%)$, followed by below the membrane $(32 \%)$ and intraosseous (22.7\%) (Fig. 3).

In the analysis between sexes, statistically significant differences were observed only in the $2 \mathrm{M}$ region, with a 
small strength of association ( $\mathrm{p}=0.036$, Phi coefficient $=0.297$ ). We observed that among males the most common location of the AAA is on the outer cortex of the lateral sinus wall $(56.3 \%)$, followed by below the membrane $(27.1 \%)$ and intraosseous (16.7\%); among females, below the membrane is most common (40.7\%), followed by intraosseous $(33.3 \%)$ and on the outer cortex of the lateral sinus wall $(25.9 \%)$ (Fig. 4).

The location of the AAA presented no statistically significant differences between sides and age ranges.

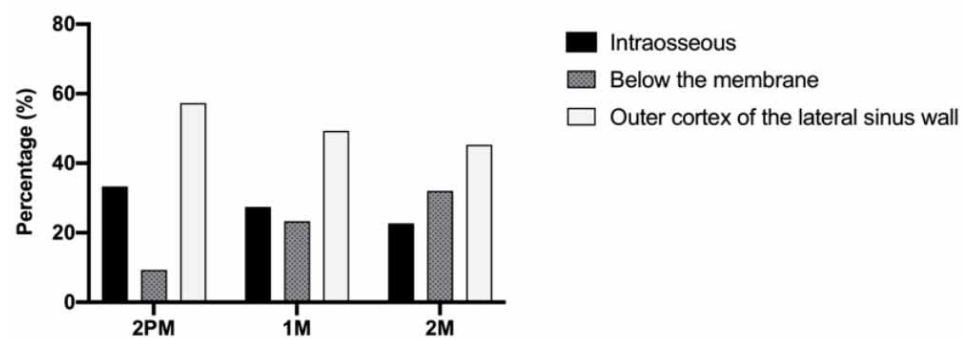

Fig. 3. Location of the AAA (percentage) in the region of $2 \mathrm{PM}, 1 \mathrm{M}$ and $2 \mathrm{M}$.

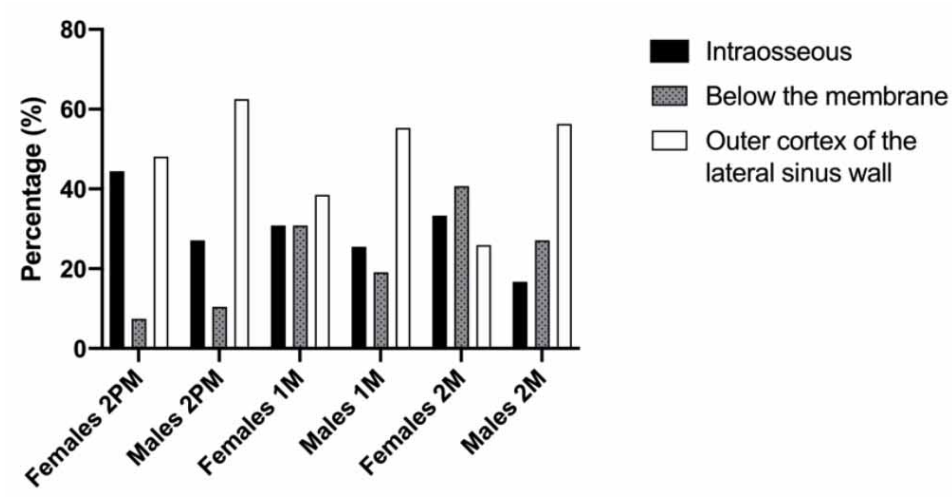

Fig. 4. Location of the AAA (percentage), by sex.

Diameter of the AAA. The mean diameter of the AAA was $1.16 \mathrm{~mm}$ $(\mathrm{SD}=0.30 \mathrm{~mm})$ in the $2 \mathrm{PM}$ region; $1.28 \mathrm{~mm}(\mathrm{SD}=0.39 \mathrm{~mm})$ in the $1 \mathrm{M}$ region, and of $1.30 \mathrm{~mm}(\mathrm{SD}=0.31 \mathrm{~mm})$ in the $2 \mathrm{M}$ region. We observed that the diameter of the AAA on the left side was significantly greater than on the right side in the $1 \mathrm{PM}, 1 \mathrm{M}$ and $2 \mathrm{M}$ regions $(\mathrm{p}<0.000)$ (Fig. $5)$.

The diameter of the AAA in the 2PM region was smaller than $1 \mathrm{~mm}$ in $15.6 \%$ of cases and between 1 and $2 \mathrm{~mm}$ in $84.4 \%$. The diameter of the AAA in the $1 \mathrm{M}$ region was smaller than $1 \mathrm{~mm}$ in 13.5 $\%$ of cases, between 1 and $2 \mathrm{~mm}$ in $83.8 \%$ and between 2 and $3 \mathrm{~mm}$ in $2.7 \%$. The diameter of the AAA in the $2 \mathrm{M}$ region was smaller than $1 \mathrm{~mm}$ in $12.2 \%$ of cases, between 1 and $2 \mathrm{~mm}$ in $82.9 \%$ and between 2 and $3 \mathrm{~mm}$ in $4.9 \%$.

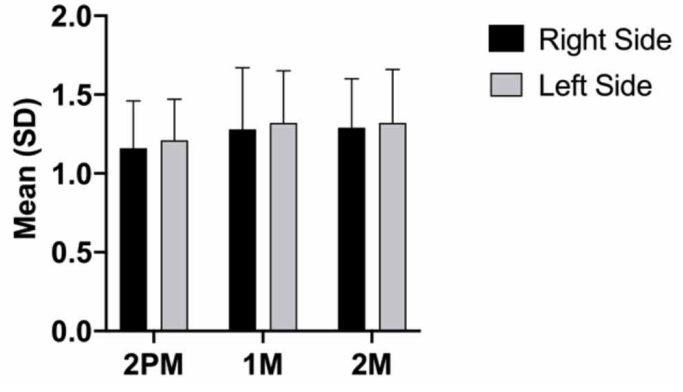

Fig. 5. Mean and standard deviation (SD), in millimetres, found for the diameter of the AAA in the region of the second premolar, first molar and second molar, by side.

Table I shows the correlation between sides for the diameters of the AAA; a very high, significant positive correlation is observed in the $2 \mathrm{M}$ region and a high significant positive correlation in the $2 \mathrm{PM}$ and $1 \mathrm{M}$ regions.

No statistically significant differences were found between sexes for the diameter, except in the $2 \mathrm{M}$ region (right side), where the mean value was greater in men $(1.60 \mathrm{~mm}, \mathrm{SD}=0.32 \mathrm{~mm})$ than in women $(1.20 \mathrm{~mm}, \mathrm{SD}=0.20 \mathrm{~mm})(\mathrm{p}=0.006)$.

No statistically significant differences in any variable were observed in the analysis of the diameter of the AAA by age range.

In the analysis between age and diameter of the AAA we observed that the diameter in the $1 \mathrm{M}$ region (right side) presented a low significant negative correlation. No statistically significant differences were found for the other variables (Table II).

Distance to the AAA. The mean distances were: $22.15 \mathrm{~mm}(\mathrm{SD}=3.38 \mathrm{~mm})$ for AAA-2PM; 18.33 $\mathrm{mm}(\mathrm{SD}=3.80 \mathrm{~mm})$ for AAA-1M and $17.34 \mathrm{~mm}$ $(\mathrm{SD}=4.13 \mathrm{~mm})$ for $\mathrm{AAA}-2 \mathrm{M}$.

In the analysis of distance by age, we observed a moderate significant positive correlation for AAA-2M (right side) and a low significant positive correlation for AAA-2M (left side) and AAA-1M (both sides). No significant correlation was found for AAA-2PM (Table III).

In the analysis between sides we observed that the mean values for AAA-2PM, AAA-1M and AAA-2M were significantly higher on the right side than the left $(p<0.000)$ (Fig. 6). 
ALVES, N.; TORRES, C. ; DEANA, N. F. \& GARAY, I. Analysis of the presence, location and morphometry of the «alveolar antral artery» by cone-beam computed tomography in Chilean adults Int. J. Morphol., 38(6):1760-1766, 2020.

Table I. Pearson's correlation coefficient (rho) and p value between left and right sides.

\begin{tabular}{lcccccc}
\hline \multicolumn{1}{c}{ Analysis } & Distance & Distance & Distance & Diameter & Diameter & Diameter \\
& AAA-2PM & AAA-1M & AAA-2M & 2PM region & 1M region & 2M region \\
\hline rho & 0.950 & 0.987 & 0.981 & 0.734 & 0.727 & 0.863 \\
p-value & $0.000^{*}$ & $0.000^{*}$ & $0.000^{*}$ & $0.000^{*}$ & $0.001^{*}$ & $0.000^{*}$ \\
\hline
\end{tabular}

* statistically significant difference.

Table II. Pearson's correlation coefficient (rho) and p value between age and diameter of the AAA in the region of the second molar, first molar and second premolar.

\begin{tabular}{lcccccc}
\hline & & Right Side & & & Left Side & \\
& Diameter & Diameter & Diameter & Diameter & Diameter & Diameter \\
\hline & 2PM region & 1M region & 2M region & 2PM region & 1M region & 2M region \\
rho & -0.147 & -0.322 & -0.257 & -0.254 & -0.020 & -0.166 \\
p-value & 0.385 & $0.043^{*}$ & 0.105 & 0.161 & 0.912 & 0.328 \\
\hline
\end{tabular}

* statistically significant difference.

Table III. Pearson's correlation coefficient (rho) and p value between age and distances, by side.

\begin{tabular}{|c|c|c|c|c|c|c|}
\hline & \multicolumn{3}{|c|}{ Right Side } & \multicolumn{3}{|c|}{ Left Side } \\
\hline & Distance & Distance & Distance & Distance & Distance & Distance \\
\hline & AAA-2PM & AAA-1M & AAA-2M & AAA-2PM & AAA-1M & AAA-2M \\
\hline rho & 0.234 & 0.398 & 0.413 & 0.275 & 0.373 & 0.360 \\
\hline $\mathrm{p}$-value & 0.198 & $0.015^{*}$ & $0.000 *$ & 0.128 & $0.023^{*}$ & $0.022 *$ \\
\hline
\end{tabular}

* statistically significant difference.

Table I shows the correlation between sides for AAA2PM, AAA-1M and AAA-2M, with a very high significant positive correlation for all the distances.

Between sexes, only AAA-2PM (right side) presented statistically significant differences; the mean values for this distance were higher in women $(22.81 \mathrm{~mm}, \mathrm{SD}=2.87 \mathrm{~mm})$ than in men $(19.67 \mathrm{~mm}, \mathrm{SD}=2.89 \mathrm{~mm})(\mathrm{p}=0.049)$.

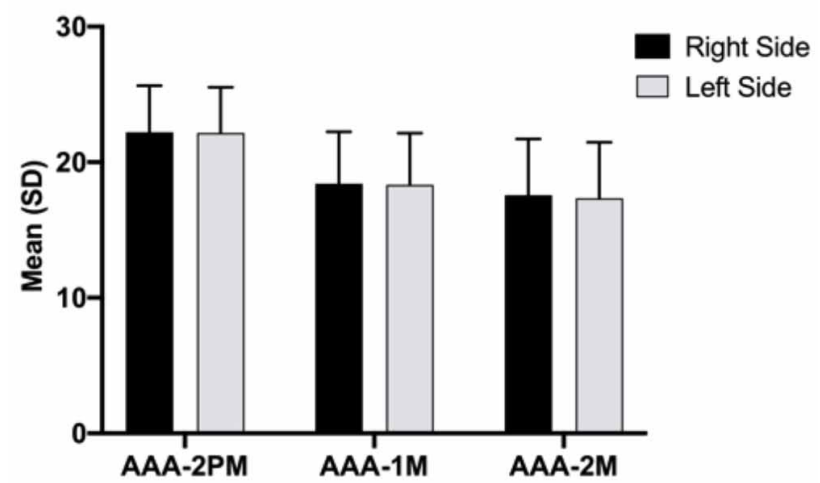

Fig. 6. Mean and standard deviation (SD), in millimetres, found for the AAA-2PM, AAA-1M and AAA-2M distances, by side.

Between age ranges we observed a statistically significant difference only for AAA-2M between individuals of 18-28 years vs. 40-49 years. On the right side the distance was smaller for the 18-28 years group ( $16.61 \mathrm{~mm}, \mathrm{SD}=1.70$ $\mathrm{mm})$ than the $40-49$ years group $(16.52 \mathrm{~mm}, \mathrm{SD}=4.07 \mathrm{~mm})$ $(\mathrm{p}=0.027)$. A similar finding was recorded on the left side, where the distance was significantly smaller for the $18-28$ years group $(16.52 \mathrm{~mm}, \mathrm{SD}=4.07 \mathrm{~mm})$ than the $40-49$ years group $(23.11 \mathrm{~mm}, \mathrm{SD}=2.62 \mathrm{~mm})(\mathrm{p}=0.035)$.

\section{DISCUSSION}

During surgical procedures like horizontal osteotomy of the maxilla, Le Fort I fracture treatment and CaldwellLuc surgeries, as well as elevation of the maxillary sinus floor, there is a potential risk of bleeding from the rami of the maxillary artery (Shahidi et al., 2016); it is therefore important to have detailed anatomical knowledge of the region. One of the principal intraoperative complications that occur during elevation of the sinus floor with lateral approach is bleeding due to lesions of the AAA (Stacchi et al.). The AAA is always present in the lateral wall of the maxillary sinus (Rosano et al., 2011) and the bleeding caused by accidental lesion can occur during opening of the lateral window (Stacchi et al.). Complications during surgical procedures, such as lesion of the AAA and perforation of the sinus membrane, have a negative impact on the clinical results, reducing implant survival rate and diminishing the formation of new bone in the region (Stacchi et al.).

In the present study we analysed the presence, location and diameter of the AAA, using CBCT, in Chilean individuals. We identified the AAA in $89.3 \%$ of the sinuses 
analysed, similar to the findings of Ilgüy et al. (2013) in a Turkish population who also reported identifying the AAA in $89.3 \%$ of patients. Note that studies in cadavers report that the AAA can be observed in $100 \%$ of the sinuses analysed (Solar et al., 1999; Traxler et al., 1999; Rosano et al., 2009). Because the calibre of the AAA is often very small, it cannot always be observed in CT and CBCT images (Mardinger et al.). Other studies analysing the presence of AAA using CT scans or CBCT report rates of between 60.3 $\%$ in a Thai population (San Aung et al., 2017) and $64.5 \%$ (Güncü et al.) for a Turkish population, $55 \%$ for an Israeli population (Mardinger et al.) and $52.9 \%$ for a North American population (Elian et al., 2005), all lower than in our investigation.

Cruz Ibañez et al. (2016) studied the distance from the alveolar antral canal to the cervical region of the tooth, finding distances of $17.35 \mathrm{~mm}$ for 2PM, $16.96 \mathrm{~mm}$ for $1 \mathrm{M}$ and $18.75 \mathrm{~mm}$ for $2 \mathrm{M}$. San Aung et al. reported the distance from the AAA to the alveolar crest, finding $15.93 \mathrm{~mm}$ $(\mathrm{SD}=3.57 \mathrm{~mm})$ for the $2 \mathrm{M}$ region, $15.82 \mathrm{~mm}(\mathrm{SD}=4.09$ $\mathrm{mm})$ for the $1 \mathrm{M}$ region and $20.35 \mathrm{~mm}(\mathrm{SD}=4.74 \mathrm{~mm})$ for the $2 \mathrm{PM}$ region. Rysz et al. also reported the distance from the AAA to the alveolar crest, finding $19.91 \mathrm{~mm}$ for the $2 \mathrm{M}$ region, $15.99 \mathrm{~mm}$ for the $1 \mathrm{M}$ region and $16.52 \mathrm{~mm}$ for the $2 \mathrm{PM}$ region. Mardinger et al., in their study in an Israeli population, also analysed the distance from the AAA to the alveolar crest, finding $19.05 \mathrm{~mm}(\mathrm{SD}=4.60 \mathrm{~mm})$ for the 2PM region, $16.92 \mathrm{~mm}(\mathrm{SD}=4.45 \mathrm{~mm})$ for the $1 \mathrm{M}$ region and $18.88 \mathrm{~mm}(\mathrm{SD}=3.86 \mathrm{~mm})$ for the $2 \mathrm{M}$ region. In the present study we analysed the distance from the AAA to the vestibular amelocemental limit; in the $2 \mathrm{PM}$ region, the AAA was more distant than in other regions, with a mean of $22.20 \mathrm{~mm}$ for the right side and $22.15 \mathrm{~mm}$ for the left side. In the $2 \mathrm{M}$ region, the AAA was located closer to the vestibular amelocemental limit than in the other regions, $17.56 \mathrm{~mm}$ for the right side and $17.34 \mathrm{~mm}$ for the left. In our study we also observed that the distance from the AAA to the amelocemental limit tends to increase with increasing age; in other words, the artery is further from the amelocemental limit in older than younger individuals.

The location of the AAA varies over its course, and all three variations (intraosseous, below the membrane, on the outer cortex of the lateral sinus wall) can be found in the lateral wall of the same maxillary sinus. In the present study, the AAA presented the highest percentage of locations on the outer cortex of the lateral sinus wall in the 2PM, $1 \mathrm{M}$ and $2 \mathrm{M}$ regions; the location below the membrane (intrasinus) presented the lowest percentage. Different findings were reported by Güncü et al. and Ilgüy et al., who reported the majority of the AAA in an intraosseous location and less than $6 \%$ on the outer cortex of the lateral sinus wall. In our study we did not find a marked sexual difference in the location of the AAA; in the $2 \mathrm{M}$ region the location on the outer cortex of the lateral sinus wall was more common in males $(56.3 \%)$ than in females $(25.9 \%)$, while below the membrane was more common in females $(40.7 \%)$ than in males $(27.1 \%)$. Ilgüy et al. also reported differences between sexes, finding that intraosseous AAA was more prevalent in males $(74.4 \%)$ than in females $(66.4$ $\%$ ), and location on the outer cortex of the lateral sinus wall was also more prevalent in males $(10 \%)$ than in females $(1.9 \%)$.

In the present study the mean value of the calibre of the AAA was between 1 and $2 \mathrm{~mm}$ in more than $80 \%$ of the cases analysed; it was smaller than $1 \mathrm{~mm}$ in between $12.2 \%$ and $15.6 \%$, and between 2 and $3 \mathrm{~mm}$ in between $2.7 \%$ and $4.9 \%$ of the cases, depending on the region analysed (2PM, 1M, 2M). No AAA was found with calibre greater than $3 \mathrm{~mm}$. Güncü et al. also reported that the majority of AAA presented a calibre between 1 and $2 \mathrm{~mm}$, and only $12.3 \%$ were larger than $2 \mathrm{~mm}$. Our findings disagree with Güncü et al. who reported that they found statistically significant differences in the calibre of the AAA between sexes but not between sides. In our study we found differences between sexes only in the right side in the $2 \mathrm{M}$ region, where the diameter was larger in men than in women; and a larger diameter on the left side than on the right. Mardinger et al., in their study in Israelis, reported that the diameter of the canal was smaller than $1 \mathrm{~mm}$ in 26 $\%$ of cases, between 1 and $2 \mathrm{~mm}$ in $22.1 \%$ of cases and between 2 and $3 \mathrm{~mm}$ in $7.0 \%$ of cases. Kang et al. reported that only $37.8 \%$ of the AAA presented a diameter greater than $1 \mathrm{~mm}$ and Ilgüy et al. found $31.1 \%$ of AAA with diameter greater than $1 \mathrm{~mm}$. Elian et al. suggested that an AAA with diameter less than $0.5 \mathrm{~mm}$ would not produce important bleeding; Mardinger et al. and Rosano et al. (2011) considered that damage to a small-calibre artery $(<2 \mathrm{~mm})$ does not affect the execution of the surgical procedure. In a systematic review, Stacchi et al. found only $0.4 \%$ haemorrhagic events in 542 sinus floor elevations with lateral approach using rotating or ultrasound instruments. In the same systematic review the authors observed that the majority of the studies reporting haemorrhagic events indicated that the event was not significant during the antrostomy (Stacchi et al.). It may be noted that lesion of the AAA during sinus surgery may cause abundant bleeding, and that it is important to preserve the integrity of the anastomosis of the PSAA and IOA in order to support the neoangiogenesis of the bone graft, improving the formation of regenerated tissue (Solar et al.). It is therefore important to analyse the region and plan the procedure carefully in order to avoid complications during surgery. 
CONCLUSIONS. In the present study, the AAA was identified by CBCT in $89.3 \%$ of the sinuses analysed, most frequently in an extraosseous location. More than $80 \%$ of the arteries presented a diameter between 1 and $2 \mathrm{~mm}$, with no important differences between sexes and age ranges. The distance from the AAA to the vestibular amelocemental limit generally increases proportionally on both sides, and there is no marked effect of sex. In younger individuals, the artery is located closer to the amelocemental limit than in older people. Based on our findings we suggest that a proper treatment plan should be prepared, including imagenological analysis, before surgical procedures to avoid possible haemorrhagic events in the region.

ALVES, N.; TORRES, C. ; DEANA, N. F. \& GARAY, I. Análisis de la presencia, ubicación y morfometría de la «arteria alvéolo-antral» por tomografía computarizada de haz cónico en adultos chilenos. Int. J. Morphol., 38 (6):1760-1766, 2020.

RESUMEN: Arteria alveolar superior posterior es responsable de la vascularización de la mucosa que recubre la pared posterior del seno maxilar, la pulpa y el tejido peridontal en el que se insertan los molares superiores. Las ramas colaterales de la arteria infraorbitaria irrigan la mucosa de las paredes anterior y lateral del seno maxilar, así como la pulpa y el periodonto de los dientes anteriores superiores y los premolares superiores. Ambas arterias presentan ramas intraóseas y extraóseas que forman una anastomosis en las paredes anterior y lateral del seno maxilar, denominada arteria alvéolo antral (AAA). El objetivo de este estudio fue analizar la presencia, localización y morfometría del AAA en una población chilena, considerando sexo, lado y edad, mediante tomografía computarizada Cone-Beam (CBCT). Se evaluaron 42 exámenes CBCT de adultos chilenos para analizar la presencia, ubicación (extraósea, intraósea o subperióstica) y diámetro ( $<1 \mathrm{~mm}, 1-2 \mathrm{~mm}, 2-3$ $\mathrm{mm},>3 \mathrm{~mm}$ ) del AAA. y la distancia del AAA al límite amelocemental del segundo premolar superior $(2 \mathrm{PM})$, primer molar superior permanente $(1 \mathrm{M})$ y segundo molar superior permanente (2M) por sexo y rango de edad. Se aplicaron la prueba de chi-cuadrado de Pearson, la prueba t de Student, ANOVA y el coeficiente de correlación de Pearson, utilizando un umbral de significancia del $5 \%$. Se encontró AAA en 75 lados (89,3\%), 38 del lado derecho $(90,5 \%)$ y 37 del lado izquierdo $(88,09 \%)$; la localización extraósea fue la más común. Más del $80 \%$ de las arterias presentaban un diámetro entre 1 y $2 \mathrm{~mm}$, sin diferencias importantes entre sexos ni rangos de edad. En individuos más jóvenes, la arteria se ubicó más cerca del límite amelocemental vestibular que en individuos mayores. La realización de un adecuado plan de tratamiento que incluya análisis imagenológico antes de los procedimientos quirúrgicos es fundamental para evitar posibles eventos hemorrágicos en la región.

PALABRAS CLAVE: Arteria alvéolo antral; Tomografía computarizada de haz cónico; Anastomosis, Arteria alveolar superior posterior; Arteria infraorbitaria; Anatomía.

\section{REFERENCES}

Alves, N. \& Cândido, P. L. Anatomía para o Curso de Odontologia Geral e Específica. $4^{\mathrm{a}}$ ed. São Paulo, Gen-Santos, 2016.

Cohen, J. Statistical Power Analysis for the Behavioral Sciences. $2^{\text {nd }}$ ed. Hillsdale (NJ), Lawrence Erlbaum and Associates, 1988.

Cruz Ibáñez, L. A.; Palacios Vivarm D. E.; Miranda Villasana, J. E.; Cazar Almache, M. \& Martínez Ojeda, P. A. Evaluación de la arteria alveolo-antral mediante tomografía volumétrica en población mexicana y su relación con levantamiento del piso del seno maxilar. Rev. ADM, 73(6):286-90, 2016.
Elian, N.; Wallace, S.; Cho, S. C.; Jalbout, Z. N. \& Froum, S. Distribution of the maxillary artery as it relates to sinus floor augmentation. Int. J. Oral Maxillofac. Implants, 20(5):784-7, 2005.

Ella, B.; Sédarat, C.; Noble, R. da C.; Normand, E.; Lauverjat, Y.; Siberchicot, F.; Caix, P. \& Zwetyenga, N. Vascular connections of the lateral wall of the sinus: surgical effect in sinus augmentation. Int. J. Oral Maxillofac. Implants, 23(6): 1047-52, 2008.

Güncü, G. N.; Yildirim, Y. D.; Wang, H. L. \& Tözüm, T. F. Location of posterior superior alveolar artery and evaluation of maxillary sinus anatomy with computerized tomography: a clinical study. Clin. Oral Implants Res., 22(10):1164-7, 2011.

Ilgüy, D.; Ilgüy, M.; Dolekoglu, S. \& Fisekcioglu, E. Evaluation of the posterior superior alveolar artery and the maxillary sinus with CBCT. Braz. Oral Res., 27(5):431-7, 2013.

Kang, S. J.; Shin, S. I.; Herr, Y.; Kwon, Y. H.; Kim, G. T. \& Chung, J. H. Anatomical structures in the maxillary sinus related to lateral sinus elevation: A cone beam computed tomographic analysis. Clin. Oral Implants Res. 24 Suppl. A100:75$81,2013$.

Khoury, F. Augmentation of the sinus floor with mandibular bone block and simultaneous implantation: a 6-year clinical investigation. Int. J. Oral Maxillofac. Implants, 14(4):557-64, 1999.

Mardinger, O.; Abba, M.; Hirshberg, A. \& Schwartz-Arad, D. Prevalence, diameter and course of the maxillary intraosseous vascular canal with relation to sinus augmentation procedure: a radiographic study. Int. J. Oral Maxillofac. Surg., 36(8):735-8, 2007.

Maridati, P.; Stoffella, E; Speroni, S.; Cicciu, M. \& Maiorana, C. Alveolar antral artery isolation during sinus lift procedure with the double window technique. Open Dent. J., 8:95-103, 2014

Nolan, P. J.; Freeman, K. \& Kraut, R. A. Correlation between Schneiderian membrane perforation and sinus lift graft outcome: a retrospective evaluation of 359 augmented sinus. J. Oral Maxillofac. Surg., 72(1):47-52, 2014

Rosano, G.; Taschieri, S.; Gaudy, J. F. \& Del Fabbro, M. Maxillary sinus vascularization: a cadaveric study. J. Craniofac. Surg., 20(3):940-3, 2009.

Rosano, G.; Taschieri, S.; Gaudy, J. F.; Weinstein, T. \& Del Fabbro, M. Maxillary sinus vascular anatomy and its relation to sinus lift surgery. Clin. Oral Implants Res., 22(7):711-5, 2011.

Rysz, M.; Ciszek, B.; Rogowska, M. \& Krajewski, R. Arteries of the anterior wall of the maxilla in sinus lift surgery. Int. J. Oral Maxillofac. Surg., 43(9):1127-30, 2014.

San Aung, C. M.; Panmekiat, S. \& Pimkhaokham, A. The study of the alveolar antral artery canal in using cone beam computed tomography. M. Dent. J., 37(1):63-9, 2017

Shahidi, S.; Zamiri, B.; Danaei, S. M.; Salehi, S. \& Hamedani, S. Evaluation of anatomic variations in maxillary sinus with the aid of cone beam computed tomography (CBCT) in a population in south of Iran. J. Dent. (Shiraz), 17(1):715,2016 .

Solar, P.; Geyerhofer, U.; Traxler, H.; Windisch, A.; Ulm, C. \& Watzek, G. Blood supply to the maxillary sinus relevant to sinus floor elevation procedures. Clin. Oral Implants Res., 10(1):34-44, 1999.

Stacchi, C.; Andolsek, F.; Berton, F. Perinetti, G.; Navarra, C. O. \& Di Lenarda, R. Intraoperative complications during sinus floor elevation with lateral approach: a systematic review. Int. J. Oral Maxillofac. Implants, 32(3):e107-e118, 2017.

Traxler, H.; Windisch, A.; Geyerhofer, U.; Surd, R.; Solar, P. \& Firbas, W. Arterial blood supply of the maxillary sinus. Clin. Anat., 12(6):417-21, 1999.

Wallace, S. S.; Tarnow, D. P.; Froum, S. J.; Cho, S. C.; Zadeh, H. H.; Stoupel, J.; Del Fabbro, M. \& Testori, T. Maxillary sinus elevation by lateral window approach: evolution of technology and technique. J. Evid. Based Dent. Pract., 12(3 Suppl.):161-71, 2012.

\section{Corresponding author: \\ Naira F. Deana}

Center for Research in Epidemiology

Economics and Oral Public Health (CIEESPO)

Faculty of Dentistry

Universidad de La Frontera

Temuco - CHILE

Received: $18-05-2020$

Accepted: $12-07-2020$

Email: naira.figueiredo@ufromail.cl 